\title{
In Vitro Induction of Xenopus Embryonic Organs Using Animal Cap Cells
}

\author{
Takashi Ariizumi, ${ }^{1}$ Tatsuo Michiue, ${ }^{2}$ and Makoto Asashima ${ }^{3,4,5}$ \\ ${ }^{1}$ Department of Agri-Production Sciences, Tamagawa University, Machida, Tokyo 194-8610, Japan; ${ }^{2}$ Department \\ of Life Sciences (Biology), Graduate School of Arts and Sciences, The University of Tokyo, Meguro, Tokyo 153- \\ 8902, Japan; ${ }^{3}$ Research Institute for Science and Technology, Tokyo University of Science, Shinjuku, Tokyo 162 - \\ 8601, Japan; ${ }^{4}$ Biotechnology Research Institute for Drug Discovery, National Institute of Advanced Industrial \\ Science and Technology (AIST), Tsukuba, Ibaraki 305-8568, Japan
}

The animal cap — the presumptive ectoderm of the blastula embryo-can differentiate into a variety of tissues belonging to the three germ layers following exposure to specific inducers. The "animal cap assay" was devised based on the pluripotency of presumptive ectodermal cells and enabled many important discoveries in the field of embryonic induction and cell differentiation. Using this system, investigators can test multiple factors in solution simultaneously to determine their inducing activities qualitatively, quantitatively, and synergistically. Furthermore, after dissociation and induction, reaggregated animal cap cells can be induced to form higher-order organs. This protocol details preoperative preparations, followed by the basic animal cap assay. Advanced protocols for the induction of kidney, pancreas, and heart are also described.

It is essential that you consult the appropriate Material Safety Data Sheets and your institution's Environmental Health and Safety Office for proper handling of equipment and hazardous materials used in this protocol.

RECIPES: Please see the end of this protocol for recipes indicated by $<R>$. Additional recipes can be found online at http://cshprotocols.cshlp.org/site/recipes.

Reagents

Activin solution (0.5-100 ng/mL human recombinant activin A [e.g., Merck Millipore, 114700] in BSA-CM)

Store stock solutions (>100 ng/mL) at $-80^{\circ} \mathrm{C}$. Avoid repeated freeze-thaw cycles.

BSA-CM $(0.1 \%[\mathrm{w} / \mathrm{v}]$ bovine serum albumin [BSA] in CM)

Adding BSA to CM reduces adsorption of inducing substances or embryonic tissues to the surfaces of plastic culture plates.

BSA-CMFCM

$\mathrm{Ca}^{2+} / \mathrm{Mg}^{2+}$-free BSA-CM is used to dissociate animal cap cells.

Dejelling solution

\footnotetext{
${ }^{5}$ Correspondence: asashi3786@gmail.com

From the Xenopus collection, edited by Hazel L. Sive.

(C) 2017 Cold Spring Harbor Laboratory Press

Cite this protocol as Cold Spring Harb Protoc; doi:10.1101/pdb.prot097410
} 


\section{Equipment}

Dissolve $4.5 \%(w / v)$ cysteine- $\mathrm{HCl}$ or $1 \%(w / v)$ sodium thioglycollate in CM. Adjust the $\mathrm{pH}$ to $7.8-8.0$ with $\mathrm{NaOH}$. Prepare fresh before use.

Embryonic Xenopus culture media $(\mathrm{CM})<\mathrm{R}>$

There are a number of media suitable for culturing embryonic Xenopus tissues.

Retinoic acid stock solution (10 mm all-trans retinoic acid [e.g., Sigma-Aldrich, R2625] in dimethyl sulfoxide) (RA)

Store 1- $\mathrm{mL}$ aliquots at $-80^{\circ} \mathrm{C}$. Avoid repeated freeze-thaw cycles.

Xenopus laevis embryos

Detailed descriptions of the methods used to obtain embryos are presented in Ariizumi et al. (2000, 2009).

Beakers, 50- and 100-mL, sterilized

Illuminator

Fiber-optic LED lights are preferred.

Incubator, $20^{\circ} \mathrm{C}-22^{\circ} \mathrm{C}$

Microscope, binocular, equipped with $10 \times$ oculars and $1 \times$ to $4 \times$ objectives

Operation dishes

To prevent embryonic tissues from adhering to glass or plastic surfaces, line Petri dishes with autoclaved 3\% $(w / v)$ agar.

Pipette bulb, silicon

Sterilize in $70 \%$ ethanol before use.

Tissue culture plates, low-adhesion, 24-well (e.g., Sumitomo Bakelite, MS-80240Z)

Tissue culture plates, low-adhesion, round-bottomed, 96-well (e.g., Sumitomo Bakelite, MS-3096UZ)

Transfer pipettes

To prepare, flame a Pasteur pipette at its center and draw it out at a $30^{\circ}-40^{\circ}$ angle. Cut pipettes such that the opening is 0.5-2-mm diameter. Flame the tip briefly to smooth the cut edges. Heat-sterilize for $2 \mathrm{~h}$ at $180^{\circ} \mathrm{C}$.

Tungsten needles

Insert a 0.2-mm tungsten wire (2-cm length) into a transfer pipette (2-mm i.d.). Flame to seal the wire in place. Bend the wire at a right angle; cut 3-5-mm from its end. Sharpen the wire electrolytically using $5 \mathrm{M} \mathrm{NaOH}$ and a $9 \mathrm{~V}$-dry cell (submerge the negative pole on a carbon point in the $\mathrm{NaOH}$ solution; attach the positive pole to the tungsten wire). Heat-sterilize for $2 \mathrm{~h}$ at $180^{\circ} \mathrm{C}$.

Watchmaker's forceps (e.g., Fontax no. 5)

Heat-sterilize for $2 \mathrm{~h}$ at $180^{\circ} \mathrm{C}$.

METHOD

Membrane Removal

To access the animal cap, the jelly coat (see online Movie 1 at cshprotocols.cshlp.org) and vitelline membrane (see online Movie 2 at cshprotocols.cshlp.org) surrounding the embryo must be removed.

1. Collect embryos in a sterilized $100-\mathrm{mL}$ beaker. Add $50 \mathrm{~mL}$ of dejelling solution.

2. Swirl for 5-10 min. Decant the dejelling solution when the jelly-free embryos begin to pack together.

3. Rinse 10 times by swirling gently with the $\mathrm{CM}$ of choice.

4. Select blastula embryos at the desired stage of development (see Nieuwkoop and Faber 1994). Use a 2-mm diameter transfer pipette and a sterilized pipette bulb to place the embryos into an agarlined Petri dish containing CM. 
T. Ariizumi et al.

5. Holding the embryo upside-down, use fine forceps to grasp the vitelline membrane. Gently tear the membrane from the embryo.

Animal Cap Dissection

The procedure is shown in online Movie 3 at cshprotocols.cshlp.org.

6. Place the blastula embryo with the animal pole facing upward in an operation dish filled with the $\mathrm{CM}$ of choice.

7. Using a tungsten needle, trim both sides of the embryo.

8. Insert the needle into the blastocoel from one side. Divide the vegetal hemisphere (i.e., the endodermal region) by pushing down the needle.

This produces a sheet of blastocoel roof with cell masses at each end.

9. Reverse the sheet. Trim away vegetal yolky cells and marginal zone cells.

10. Trim the sheet (i.e., the animal cap) into a $0.5 \times 0.5-\mathrm{mm}$ square.

Animal Cap Culture

The procedure is shown schematically in online Movie 4 at cshprotocols.cshlp.org. Use a transfer pipette (0.5- to 1-mm diameter) to handle the animal caps.

11. Transfer five to 10 animal caps into activin solution of the desired concentration. Place them such that the inner blastocoel side faces upward. Incubate for a defined period (e.g., 3 h).

Depending on the concentration used, activin can induce a variety of tissues and organs (Table 1).

12. Transfer the animal caps to a dish filled with BSA-CM. Wash them by pipetting gently.

13. Incubate the caps in fresh BSA-CM for $3-4 \mathrm{~d}$ at $20^{\circ} \mathrm{C}-22^{\circ} \mathrm{C}$.

The explants will show obvious histodifferentiation patterns at the end of the culture.

Kidney Induction

Simultaneous treatment with $R A$ and activin can induce the generation of the pronephros (i.e., the embryonic kidney) (see online Movie 5 at cshprotocols.cshlp.org). The original protocol (Moriya et al. 1993) used Steinberg's Solution as the $C M$.

14. Transfer 10 animal caps from late blastulae (i.e., stage 9) to a well of a 24-well tissue culture plate containing "Test Solution K" (i.e., $10 \mu \mathrm{L}$ of RA stock solution and $990 \mu \mathrm{L}$ of $10-\mathrm{ng} / \mathrm{mL}$ activin solution). Incubate for $3 \mathrm{~h}$ at $20^{\circ} \mathrm{C}$.

15. Wash the caps in BSA-CM. Culture in fresh BSA-CM for $3 \mathrm{~d}$ at $20^{\circ} \mathrm{C}$.

After $3 d$, pronephric tubules should be observable inside the thin epidermal vesicle.

Pancreas Induction

Sequential treatment with activin and RA can induce formation of the pancreas (see online Movie 5 at cshprotocols. cshlp.org).

16. Transfer 10 animal caps from late blastulae (i.e., stage 9) to a well of a 24 -well tissue culture plate containing "Test Solution P1" (100-ng/mL activin solution). Incubate for $1 \mathrm{~h}$ at $20^{\circ} \mathrm{C}$.

17. After washing briefly with BSA-CM, incubate in fresh BSA-CM for $5 \mathrm{~h}$ at $20^{\circ} \mathrm{C}$.

18. Transfer the animal caps to "Test Solution P2" (i.e., $10 \mu \mathrm{L}$ of RA stock solution in $990 \mu \mathrm{L}$ of BSA$\mathrm{CM})$. Incubate for $1 \mathrm{~h}$ at $20^{\circ} \mathrm{C}$.

19. Wash the animal caps with BSA-CM. Culture in fresh BSA-CM for $3 \mathrm{~d}$ at $20^{\circ} \mathrm{C}$.

Pancreatic differentiation can be characterized by histological examination and/or the expression of molecular markers (e.g., $p d x 1$, insulin). 
TABLE 1. Examples of tissues and organs induced from Xenopus animal caps by activin and other factors

\begin{tabular}{|c|c|c|c|c|}
\hline Tissues and organs & Methods & Notes & Markers & References \\
\hline \multicolumn{5}{|l|}{ Ectoderm } \\
\hline Epidermis & $\begin{array}{l}\text { Animal cap assay (Steps } \\
\text { 11-13) }\end{array}$ & Induced by $0.5-50 \mathrm{ng} / \mathrm{mL}$ activin & $x k 81 a 1$ & $\begin{array}{l}\text { Asashima et al. 1990; Ariizumi } \\
\text { et al. } 1991\end{array}$ \\
\hline $\begin{array}{l}\text { Brain (forebrain, } \\
\text { hindbrain); Spinal cord }\end{array}$ & $\begin{array}{l}\text { Combination of treated and } \\
\text { untreated animal caps }\end{array}$ & $\begin{array}{l}\text { Induced from untreated animal } \\
\text { caps by animal caps treated with } \\
>50 \mathrm{ng} / \mathrm{mL} \text { activin }\end{array}$ & otx2, sox 2, foxg 1 & Ariizumi and Asashima 1994 \\
\hline $\begin{array}{l}\text { Eye (lens, neural retina, } \\
\text { retinal pigment } \\
\text { epithelium); Ear vesicle }\end{array}$ & As above & Induced secondarily from brain & pax6, six3, rax & $\begin{array}{l}\text { Ariizumi and Asashima 1994; } \\
\text { Sedohara et al. } 2003\end{array}$ \\
\hline \multicolumn{5}{|l|}{ Mesoderm } \\
\hline Notochord & $\begin{array}{l}\text { Animal cap assay (Steps } \\
\text { 11-13) }\end{array}$ & $\begin{array}{l}\text { Induced by high concentrations } \\
\qquad>50 \mathrm{ng} / \mathrm{mL}) \text { of activin }\end{array}$ & chrd, not & $\begin{array}{l}\text { Asashima et al. 1990; Ariizumi } \\
\text { et al. } 1991\end{array}$ \\
\hline Skeletal muscle & As above & $\begin{array}{l}\text { Induced by intermediate } \\
\text { concentrations }(5-50 \mathrm{ng} / \mathrm{mL}) \text { of } \\
\text { activin }\end{array}$ & $\begin{array}{l}\text { myod, myf5, } \\
\text { mrf4 }\end{array}$ & $\begin{array}{l}\text { Asashima et al. 1990; Ariizumi } \\
\text { et al. } 1991\end{array}$ \\
\hline Coelomic epithelium & As above & $\begin{array}{l}\text { Induced by low concentrations } \\
(0.5-5 \mathrm{ng} / \mathrm{mL}) \text { of activin }\end{array}$ & - & $\begin{array}{l}\text { Asashima et al. 1990; Ariizumi } \\
\text { et al. } 1991\end{array}$ \\
\hline $\begin{array}{l}\text { Blood cells; Blood } \\
\text { vessel }\end{array}$ & As above & $\begin{array}{l}\text { Induced by low concentrations } \\
\qquad(0.5-1 \mathrm{ng} / \mathrm{mL}) \text { of activin }\end{array}$ & runx2, spib, mpo & $\begin{array}{l}\text { Asashima et al. 1990; Ariizumi } \\
\text { et al. 1991; Miyanaga et al. } \\
\text { 1999; Nagamine et al. } 2007\end{array}$ \\
\hline $\begin{array}{l}\text { Pronephros (glomus, } \\
\text { tubule, duct) }\end{array}$ & $\begin{array}{l}\text { Multiple treatments with } \\
\text { activin and retinoic acid } \\
\text { (Steps 14-15) }\end{array}$ & $\begin{array}{l}\text { Induced by simultaneous treatment } \\
\text { with } 10 \mathrm{ng} / \mathrm{mL} \text { activin and } 0.1 \\
\mathrm{~mm} \text { retinoic acid }\end{array}$ & $\begin{array}{r}\text { wnt4, pax2, } \\
\text { sall1, wt1 }\end{array}$ & $\begin{array}{c}\text { Moriya et al. 1993; Chan et al. } \\
\text { 1999; Osafune et al. } 2002\end{array}$ \\
\hline Heart & $\begin{array}{l}\text { Dissociation and } \\
\text { reaggregation of animal } \\
\text { cap cells (Steps 21-24) }\end{array}$ & $\begin{array}{l}\text { Individual cells are treated with } \\
100 \mathrm{ng} / \mathrm{mL} \text { activin during } \\
\text { reaggregation }\end{array}$ & $\begin{array}{l}n k \times 2.5, \text { gata } 4 \\
\text { tbx } 5, \text { tnni3 }\end{array}$ & Ariizumi et al. 2003 \\
\hline Craniofacial cartilage & $\begin{array}{l}\text { Combination of treated and } \\
\text { untreated animal caps }\end{array}$ & $\begin{array}{l}\text { Induced from untreated animal } \\
\text { caps by animal caps treated with } \\
100 \mathrm{ng} / \mathrm{mL} \text { activin }\end{array}$ & dll4, col2a 1, alx 1 & Furue et al. 2002 \\
\hline \multicolumn{5}{|l|}{ Endoderm } \\
\hline Pharynx; Intestine & $\begin{array}{l}\text { Combination of treated and } \\
\text { untreated animal caps }\end{array}$ & $\begin{array}{l}\text { Animal caps treated with }>50 \mathrm{ng} / \\
\mathrm{mL} \text { activin form pharynx and } \\
\text { intestine in recombinants }\end{array}$ & fabp2, darmin & Ariizumi and Asashima 1994 \\
\hline Pancreas & $\begin{array}{l}\text { Multiple treatments with } \\
\text { activin and retinoic acid } \\
\text { (Steps 16-19) }\end{array}$ & $\begin{array}{l}\text { Induced by sequential treatment } \\
\text { with } 100 \mathrm{ng} / \mathrm{mL} \text { activin and } 0.1 \\
\text { mM retinoic acid }\end{array}$ & pdx 1 , mist 1 , ins & Moriya et al. 2000 \\
\hline Liver & $\begin{array}{l}\text { Animal cap assay (Steps } \\
\text { 11-13) }\end{array}$ & $\begin{array}{l}\text { Yolk-rich endoderm induced by } \\
100 \mathrm{ng} / \mathrm{mL} \text { activin forms liver } \\
\text { when transplanted into larvae }\end{array}$ & $\begin{array}{l}\text { hhex, ambp, } \\
\text { transferrin, } \\
\text { albumin }\end{array}$ & Ariizumi et al. 2003 \\
\hline
\end{tabular}

\section{Dissociation and Reaggregation of Animal Caps for Heart Induction}

Cell-to-cell interactions can be studied by examining the activity of animal caps dissociated into individual cells. Here, we describe a dissociation/reaggregation protocol to induce heart formation (see online Movie 6 at cshprotocols cshlp.org). The original method (Ariizumi et al. 2003) used Holtfreter's Solution as the CM.

20. Dissect five to 10 animal caps from mid-blastulae (i.e., stage 8) in an operation dish filled with CM.

21. Transfer the caps to a $35-\mathrm{mm}$ diameter Petri dish containing BSA-CMFCM.

This is crucial to eliminate $\mathrm{Ca}^{2+}$ and $\mathrm{Mg}^{2+}$ cations that might be transferred from the operation dish.

22. Transfer five to 10 animal caps into a single well of a 96-well tissue culture plate containing $100 \mu \mathrm{L}$ of BSA-CMFCM. Incubate for $20 \mathrm{~min}$.

23. Replace the BSA-CMFCM with $100 \mu \mathrm{L}$ of $100-\mathrm{ng} / \mathrm{mL}$ activin solution. Disperse the cells by pipetting gently. Incubate for $5 \mathrm{~h}$.

24. Transfer the newly formed spherical "reaggregates" into a single well filled with $200 \mu \mathrm{L}$ of BSA-CM.

The reaggregated cells will begin to beat rhythmically within $3 \mathrm{~d}$ at $20^{\circ} \mathrm{C}$. 
When treated with a mesoderm-inducer such as activin, animal caps are competent for in vitro organogenesis from stage 7 (early blastula) up to stage 9 (late blastula). Thus, accurate staging of embryos is vital to the success of in vitro organogenesis. The late blastula (stage 9) is used as the standard for the animal cap assay, although for the heart induction described in this protocol, midblastula embryos (stage 8) are most suitable. The size of the animal caps is also critical. The number of cells in the explant will affect the efficacy of tissue differentiation and organ formation. A large cap might be contaminated with cells from the marginal zone, which can differentiate autonomously into mesodermal tissues. The most reliable animal cap size is $0.5 \times 0.5 \mathrm{~mm}$. Finally, the duration of the exposure of the animal caps to an inducer can influence the differentiation pattern. For example, a brief exposure (10 $\mathrm{min}$ ) to $10-\mathrm{ng} / \mathrm{mL}$ activin causes the differentiation of ventral mesoderm, whereas a longer exposure $(>3 \mathrm{~h})$ to the same dose induces dorsal mesoderm differentiation (Ariizumi et al. 1991).

\section{RECIPE}

Embryonic Xenopus Culture Media (CM)

\begin{tabular}{|c|c|c|c|c|c|}
\hline Components (mM) & $\begin{array}{c}\text { Holtfreter's } \\
\text { solution }\end{array}$ & $\begin{array}{l}\text { Modified } \\
\text { Barth's } \text { solution }^{\text {a }}\end{array}$ & $\begin{array}{c}\text { Marc's } \\
\text { modified } \\
\text { Ringers }^{\mathrm{a}}\end{array}$ & $\begin{array}{l}\text { Normal } \\
\text { amphibian }^{\text {medium }}\end{array}$ & $\begin{array}{c}\text { Steinberg's } \\
\text { solution }\end{array}$ \\
\hline $\mathrm{NaCl}$ & $60.00^{\mathrm{b}}$ & 88.00 & 100.00 & 110.00 & $60.00^{\mathrm{b}}$ \\
\hline $\mathrm{KCl}$ & 0.67 & 1.00 & 2.00 & 2.00 & 0.67 \\
\hline $\mathrm{CaCl}_{2}^{\mathrm{c}}$ & 0.90 & 0.41 & 2.00 & - & - \\
\hline $\mathrm{Ca}\left(\mathrm{NO}_{3}\right)_{2}^{\mathrm{c}}$ & - & 0.33 & - & 1.00 & 0.34 \\
\hline $\mathrm{MgCl}_{2}^{\mathrm{c}}$ & - & - & 1.00 & - & - \\
\hline $\mathrm{MgSO}_{4}^{\mathrm{c}}$ & - & 0.82 & - & 1.00 & 0.83 \\
\hline EDTA & - & - & - & 0.10 & - \\
\hline Sodium phosphate, $\mathrm{pH} 7.50$ & - & - & - & 2.00 & - \\
\hline $\mathrm{NaHCO}_{3}$ & $0.20^{\mathrm{d}}$ & 2.40 & - & 1.00 & - \\
\hline HEPES & $4.60^{\mathrm{d}}$ & 10.00 & 5.00 & - & 10.00 \\
\hline $\mathrm{pH}$ & 7.60 & 7.40 & 7.40 & 7.40 & 7.40 \\
\hline
\end{tabular}

${ }^{\mathrm{a}}$ Use at half-strength (i.e., $0.5 \times$ ) for culture media.

${ }^{\mathrm{b}}$ To prevent animal caps from curling, increase the $\mathrm{NaCl}$ concentration from $60 \mathrm{~mm}$ to $90 \mathrm{~mm}$. However, note that animal cap cells will differentiate into neural tissue autonomously when exposed to high $\mathrm{NaCl}$ concentrations.

${ }^{\mathrm{c}}$ Omit these components when preparing $\mathrm{Ca}^{2+} / \mathrm{Mg}^{2+}$-free culture media (CMFCM).

${ }^{\mathrm{d}}$ For Holtfreter's Solution, use either $\mathrm{NaHCO}_{3}$ or HEPES.

Sterilize the $\mathrm{CM}$ of choice by autoclaving for $20 \mathrm{~min}$ at $121^{\circ} \mathrm{C}$. Add antibiotics such as kanamycin sulfate $(0.1 \mathrm{~g} / \mathrm{L})$ to avoid bacterial contamination.

\section{ACKNOWLEDGMENTS}

We wish to thank Dr. Shuji Takahashi for technical support and many insightful discussions over the years. 


\section{REFERENCES}

Ariizumi T, Asashima M. 1994. In vitro control of the embryonic form of Xenopus laevis by activin A: Time and dose-dependent inducing properties of activin A-treated ectoderm. Dev Growth Differ 36: 499-507.

Ariizumi T, Sawamura K, Uchiyama H, Asashima M. 1991. Dose and timedependent mesoderm induction and outgrowth formation by activin A in Xenopus laevis. Int J Dev Biol 35: 407-414.

Ariizumi T, Takano K, Asashima M, Malacinski GM. 2000. Bioassays of inductive interactions in amphibian development. Methods Mol Biol 135: 89-112.

Ariizumi T, Kinoshita M, Yokota C, Takano K, Fukuda K, Moriyama N, Malacinski GM, Asashima M. 2003. Amphibian in vitro heart induction: A simple and reliable model for the study of vertebrate cardiac development. Int J Dev Biol 47: 405-410.

Ariizumi T, Takahashi S, Chan TC, Ito Y, Michiue T, Asashima M. 2009. Isolation and differentiation of Xenopus animal cap cells. Curr Protoc Stem Cell Biol Chapter 1: Unit: 1D.5.

Asashima M, Nakano H, Shimada K, Kinoshita K, Ishii K, Shibai H, Ueno N. 1990. Mesodermal induction in early amphibian embryos by activin A (erythroid-differentiation factor). Roux Arch Dev Biol 198: 330-335.

Chan TC, Ariizumi T, Asashima M. 1999. A model system for organ engineering: Transplantation of in vitro induced embryonic kidney. Naturwissenschaften 86: 224-227.

Furue M, Myoishi Y, Fukui Y, Ariizumi T, Okamoto T, Asashima M. 2002. Activin A induces craniofacial cartilage from undifferentiated Xenopus ectoderm in vitro. Proc Natl Acad Sci 99: 15474-15479.
Miyanaga Y, Shiurba R, Asashima M. 1999. Blood cell induction in Xenopus animal cap explants: Effects of fibroblast growth factor, bone morphogenetic proteins, and activin. Dev Genes Evol 209: 69-76.

Moriya N, Uchiyama H, Asashima M. 1993. Induction of pronephric tubules by activin and retinoic acid in presumptive ectoderm of Xenopus laevis. Dev Growth Differ 35: 123-128.

Moriya N, Komazaki S, Takahashi S, Yokota C, Asashima M. 2000. In vitro pancreas formation from Xenopus ectoderm treated with activin and retinoic acid. Dev Growth Differ 42: 593-602.

Nagamine K, Furue M, Fukui A, Matsuda A, Hori T, Asashima M. 2007. Blood cell and vessel formation following transplantation of activintreated explants in Xenopus. Biol Pharm Bull 30: 1856-1859.

Nieuwkoop PD, Faber J (eds.). 1994. Normal table of Xenopus laevis (Daudin): A systematical \& chronological survey of the development from the fertilized egg till the end of metamorphosis. Garland Publishing, New York.

Osafune K, Nishinakamura R, Komazaki S, Asashima M. 2002. In vitro induction of the pronephric duct in Xenopus explants. Dev Growth Differ 44: 161-167.

Sedohara A, Komazaki S, Asashima M. 2003. In vitro induction and transplantation of eye during early Xenopus development. Dev Growth Differ 45: 463-471. 


\section{In Vitro Induction of Xenopus Embryonic Organs Using Animal Cap Cells}

Takashi Ariizumi, Tatsuo Michiue and Makoto Asashima

Cold Spring Harb Protoc; doi: 10.1101/pdb.prot097410 originally published online October 30, 2017

\begin{aligned} & \hline $\begin{array}{r}\text { Email Alerting } \\ \text { Service }\end{array}$ Receive free email alerts when new articles cite this article - click here. \\ & \hline $\begin{array}{c}\text { Subject } \\ \text { Categories }\end{array} \begin{array}{c}\text { Browse articles on similar topics from Cold Spring Harbor Protocols. } \\ \text { Developmental Biology (728 articles) } \\ \text { Explant Culture }(64 \text { articles }) \\ \text { Xenopus (210 articles) }\end{array} \\ &$\hline\end{aligned}

